\title{
Hogyan csapjuk az online szelet az Y generáció számára?
}

\section{Bevezetés}

Tanulmányomban bemutatom, hogy online eszközök segítségével a felsőoktatási könyvtári szférában hogyan tudjuk leghatékonyabban elérni az Y generációt, tehát azokat a fiatalokat, akik már úgy nőttek fel, hogy kommunikációjukban jelentős szerepet kaptak azt internetes kapcsolatteremtési lehetőségek. Látni fogjuk, hogy másképpen célszerü velük kommunikálni, mint például azokkal, akik csak felnőtt korukban találkozhattak az online kommunikációs lehetőségekkel.

\section{Generációk ${ }^{1}$}

Az információs társadalom az elmúlt évtizedekben a szemünk előtt alakult ki, köszönhetően az infokommunikációs eszközök rohamos fejlődésének. Ezekhez az új kapcsolatteremtési lehetőségekhez különböző módon viszonyulnak az egyének. Ezeket különbözö aspektusból vizsgálhatjuk (pl. iskolázottság, lakóhely), de a legszegmentálhatóbb különbségekkel akkor találkozunk, ha életkor szerint vizsgálódunk. ${ }^{2}$ Ez alapján 6 élő generációt különböztetünk meg, melyek között az átmenet természetesen folyamatos.

Veteránok: az 1928 és 1945 között születettek tartoznak ebbe a csoportba, ők találkoztak/találkoznak legidősebb korban az internetes kommunikáció lehetőségeivel. Akkor nőttek fel, amikor még a telefonvonalak kiépítése lassú ütemben zajlott, így legtöbbjük számára gyerekkorban valós idejü, kétirányú kommunikáció kizárólag akkor volt kivitelezhető, ha fizikailag egy helyen tartózkodtak a felek. Többnyire nehezen, vagy egyáltalán nem használnak online eszközöket kapcsolattartásra, félnek a számukra „ismeretlen” közegtől, és a hagyományos csatornákat részesítik előnyben.

Baby boomerek: ebbe a generációba azokat soroljuk, akik 1946 és 1964 között születtek. Ök már érdeklődőbbek a modern eszközök iránt, kevésbé tartanak tőlük. Ez leginkább annak köszönhetö, hogy az utánuk következő korosztály már aktívan használja ezeket az eszközöket, így ez a generáció a gyermekei révén már testközelből szemlélheti, hogyan müködik az online kommunikáció. Érdeklődés esetén akár azonnal ki is tudja próbálni, van segítsége a lehetőségek megismerésében és a használat elsajátításában. Sokan lelkes online tartalomfo-

${ }^{1}$ Tarné Éder Marianna: Generációk - ,árkok”, szakadékok. http://tarmarianna.blogspot.hu/[-] 2012/03/generaciok-arkok-szakadekok.html '(2016. augusztus 15.)

${ }^{2}$ Vincze Anikó: Generációk az információs társadalomban. = Belvedere Meridionale, 25. évf. 2013. 3. sz. 97-116. p. 
gyasztókká válnak, azonban a veszélyekre kevésbé gondolnak, könnyedén megadják például bankkártyaadataikat.

X generáció: az 1965 és 1979 között született „karrierista nemzedék” számára munkájuk miatt már elkerülhetetlen, hogy használják az online kommunikáció eszközeit, de kapcsolattartás terén továbbra is előnyben részesítik a személyes kontaktust.

Y generáció: a tanulmány szempontjából a leglényegesebb generáció, mert ők a jelenlegi egyetemista nemzedék, az 1980 és 1994 között születettek. Náluk már gyerek- vagy fiatalkorban megjelent az online kommunikáció, így hasonló (vagy jelentősebb) szerepet kap életükben, mint a hagyományos kapcsolattartási formák. Minden információhoz azonnal szeretnének hozzájutni. Alapvető kapcsolattartási formának tekintik a netes lehetőségeket, de ezt még helyhez kötöttebben élik meg, például előnyben részesítik az asztali eszközöket.

Z generáció: az Y generációhoz képest kisebb számban, de már ők is átlépték a felsőoktatási intézmények küszöbét, hiszen az 1995-2010 között született fiatalokról van szó. Ök azok, akik már úgy nőttek fel, hogy számukra az internet ugyanolyan alapvető „közmü”, mint a gáz- vagy a vízszolgáltatás. „Digitális bennszülötteknek" is szokás őket nevezni. Számukra az offline lét gyakorlatilag elképzelhetetlen, előnyben részesítik a mobileszközöket, melyekkel bárhol a világban azonnal kapcsolatba léphetnek a meglehetősen nagy - ugyanakkor felületes - baráti köreikkel. A szimultán online és „,valóságos” létnek köszönhetöen jók figyelemmegosztásban, ugyanakkor kevésbé képesek egy-egy tevékenységben alaposabban elmélyülni. Ebből a generációból sokan netfüggővé válnak/ váltak, akik, hasonlóan egy szenvedélybetegségben szenvedőhöz, képtelenek szüneteltetni a közösségi oldalak használatát.

Alfa generáció: témámat tekintve ők még nem érintettek, de fontos megemlíteni a 2010 után születetteket is. Ők már azelött elkezdik használni az online kommunikációs eszközöket, mielőtt például írni vagy olvasni megtanulnának.

Áttekintve az egyes generációk általános jellemzőit, megállapítható, hogy más a hozzáállásuk az online kommunikációs eszközökhöz. Kisebb-nagyobb mértékben már minden generáció használja ezeket a lehetöségeket, de másképp kell kommunikálni velük ezeken a csatornákon, ha azt akarjuk, az egyes nemzedékeket elérjék a nekik szánt üzenetek.

A továbbiakban elsősorban az ELTE Egyetemi Könyvtár tapasztalatain keresztül azt fogom bemutatni, hogy az Y generációval milyen platformokon célszerü kommunikálnunk a közösségi médián keresztül. Fontos hangsúlyozni, hogy az említett példákon túl az Egyetemi Könyvtár más típusú-tartalmú bejegyzéseket is közzétesz, melyekkel más korcsoportokat céloz, de ez most nem témája jelen írásnak. 


\section{Facebook $^{3}$}

Első helyen nem is lehetne mással kezdeni, mint a legtöbb felhasználóval rendelkezö közösségi oldallal. Az Y generáció többsége már évek óta jelen van ezen a felületen, napi kommunikációjuk jelentős részét bonyolítják itt, legyen szó akár a saját magukkal kapcsolatos bejegyzések közzétételéről vagy csetelésről. ${ }^{4}$ A könyvtárak jelentős hányada is képviselteti magát (legalább ezen az egy) közösségi oldalon. ${ }^{5}$ Nézzük meg, tapasztalataink alapján milyen alapvető praktikákat célszerü szem előtt tartani, ha az egyetemista korosztályt szeretnénk elérni! Egyetlen mérőszámunk, amit használni tudunk a bejegyzéseink hatékonyságával kapcsolatban, a kiváltott interakció mértéke: tehát hányan reagálnak rá például lájkolással vagy hozzászólással, azonban itt nincs lehetőségünk a kor szerinti megoszlást figyelni. Követöink kétharmada tartozik az Y és X generáció tagjai közé, ezért a levont következtetések nem feleltethetők meg kizárólag a fiatal generációk használati szokásainak, de mindenképp irányadók lehetnek abban a tekintetben, hogy milyen szempontokat érdemes szem előtt tartani bejegyzések közzétételénél, hogy ebből a korosztályból is minél több visszajelzést váltsanak ki.

Mikor posztoljunk? Tapasztalataink szerint több okból is a kora esti órákban legcélszerübb kitenni a bejegyzéseket. Ilyenkor a más Facebook-oldalak által publikált „üzleti” bejegyzésekből már kevesebb van, így nagyobb eséllyel jelenik meg posztunk követőinknél. Továbbá látogatási statisztikáink is egyértelmüen mutatják, hogy ebben az időszakban a legmagasabb a bejelentkezett követők száma, így több személytől várhatunk azonnali reakciót bejegyzéseinkre.

Érdemes-e hétvégén posztolni? Igen! Erre részben az előző pontban találjuk a magyarázatot. Hétvégén, szabadnapokon kevesebb a más oldalak által publikált poszt, így nagyobb eséllyel jelenik meg a mi bejegyzésünk a követőknél.

Milyen típusú bejegyzéseket tegyünk közzé? Három típus emelhető ki, amik általában magasabb reakciószámot érnek el a hagyományos, szöveges bejegyzéseknél: a fényképek, a videók és a kérdések.

Milyen hosszú legyen egy Facebook-poszt? Minden tartalomhoz - még képekhez is - illik szöveget írni. Ez viszont legyen minél rövidebb, lényegre törőbb, lehetőleg 50, maximum 100 karakter hosszú, mert az ennél hosszabb szövegü bejegyzések kevesebb interakciót váltanak ki a fiatalok körében. Saját ismerősi körömben is tapasztalom, hogy ebböl a korosztályból sokan úgy gördítik végig az üzenőfalukat, hogy egy-egy bejegyzésre körülbelül 1 másodpercet szánnak, és ez alapján döntik el, hogy lájkolják-e vagy sem, majd görgetnek is tovább. Ennyi időbe nem fér bele hosszú szövegek elolvasása.

${ }^{3}$ Elérhetö: http://facebook.com.

${ }^{4}$ Pótó Zsuzsanna: Közösségi kapcsolatok a virtuális térben - a Facebook-használat statisztikai elemzése. $=$ Acta Sociologica: Pécsi Szociológiai Szemle, 5. évf. 2012. 1. sz. 151-160. p.

${ }^{5}$ Fodor János: A megosztó hivatás. Könyvtári jelenlét a Facebook közösségi oldalon 2013/2014ben. = Tudományos és Müszaki Tájékoztatás, 61. évf. 2014. 7-8. sz. 275-295. p. 
Az alábbiakban áttekintem, hogy milyen tartalmú bejegyzések azok, melyeket tapasztalataink szerint könyvtárként közzétehetünk, és kiválthatjuk vele a fiatalok tetszését.

a) „Színfalak mögötti” fényképes bejegyzések, illetve azok a fotók, melyek olyan részről örökítik meg a könyvtárt, amire a látogatónak nincs lehetősége. Példaként meg lehet említeni az Egyetemi Könyvtár 2016. augusztus 26-i bejegyzését, mely a könyvtárépület tetőjéről mutatja meg a Gellért-hegyet, úgy, hogy a könyvtár kupolája is látszik rajta, illetve a 2016. május 26-i bejegyzést, ahol az olvasóteremben jelenlévők a napfénytetőn keresztül lettek lefényképezve.

b) Fontos a bejegyzéseinkkel azt is tükrözni, hogy „messzebb is látunk az orrunknál", könyvtár esetében a falainknál. Ezzel közelebb kerülhetünk a követőinkhez, hiszen látják, hogy nemcsak a munka megszállottjai dolgoznak a könyvtárakban, hanem ugyanolyan emberek, mint bárki más, akik figyelnek a környezetükre is. 2016. május 20 -án például a főigazgatói szoba ablakából tökéletesen megfigyelhető varjúcsaládról tettünk ki fényképet.

c) Bár ez a korosztály kevésbé nyitott kulturális tartalmakra, megfelelő tálalással az ilyen jellegü bejegyzéseket is el tudjuk juttatni hozzájuk. Ha például idézetet akarunk közzétenni, azt ne egyszerủ szöveges bejegyzésként tegyük, hanem helyezzük rá egy figyelemfelkeltő fényképre, így kevesebben fognak átgörgetni rajta.

d) Már többször említésre kerültek a fényképek, azonban azt is nagyon fontos hangsúlyozni ezekkel kapcsolatban, hogy minél jobb minőségü képeket tegyünk közzé. Rossz minőségü, nehezen kivehető tartalmú bejegyzésekkel nemhogy nem szerezhetünk lájkokat, akár még meglévő követőink közül is veszíthetünk.

e) Olykor a könyvtárak is élhetnek a tipikus lájkvadász bejegyzéssel: ha a könyvtári témájú bejegyzésünkkel kapcsolatba hozható kisgyermek vagy kisállat, érdemes fényképet posztolnunk ezekről. Az ilyen „cukiságok” jellemzően magas reakciószámot hoznak.

f) Célszerủ odafigyelni az aktuális online őrületekre is, melyek sokszor csak pár napig tartanak, ezért ajánlatos gyorsan reagálni rájuk. Például néhány hónapja a Pokemon Go nevezetủ mobiltelefonos alkalmazással összefüggésben az Egyetemi Könyvtárból is posztoltunk „Pokemont” 2016. július 21-én.

g) Humoros bejegyzések is helyt kaphatnak könyvtárak Facebook-oldalain, például mémek felhasználásával, melyeket a könyvtárral kapcsolatba hozható tartalommal töltünk meg. 2015. december 18-án Batman és Robin vitatkozott kicsit a könyvtárakról az Egyetemi Könyvtár Facebook-oldalán.

h) Magas reakciószámot hozhat az is, ha a Facebook egyes újításait az elsők között próbáljuk ki. 2016. július 13-án a pár nappal korábban elérhetővé vált funkció, a 360 fokos gömbpanoráma lehetőségének alkalmazásával fénykép formájában lehetett körülnézni az olvasótermünkben. 
i) Mivel könyvtárakkal meglehetősen sok téma összefüggésbe hozható, így akár egy-egy aktuális világeseményről is tudósíthatunk. Ebben az Országos Széchényi Könyvtár jeleskedett az idei olimpiai időszak alatt. Az elsők között tudósítottak a magyar érmekről, melyeket a követőik kifejezetten magas számú lájkkal és megosztással értékeltek.

A bejegyzések tartalmán túl fontos odafigyelni más tevékenységekre is, ha könyvtárként Facebook-oldalt üzemeltetünk. Tartsuk naprakészen adatlapunkat, hiszen nagyon sokan (például az Y generáció tagjai) elsődlegesen innen tájékozódnak, és csak egy második lépés a könyvtár hivatalos honlapjának felkeresése.

Nagyon fontos az is, hogy egy bejegyzéssel nem csak addig vannak tennivalóink, ameddig közzétesszük. Amennyiben hozzászólás érkezik a posztunkhoz, illik arra reagálni. Ugyanez a teendő a privát üzenetekkel is, melyekre minél gyorsabban kell válaszolnunk, hiszen a Facebook ez alapján kategorizálja oldalunkat. Ha a „Gyors válasz” besorolást kapjuk, akkor nagyobb eséllyel számíthatunk megkeresésre ezen a csatornán keresztül is.

Bár most kifejezetten az Y generáció felöl közelítve tettem javaslatot a Facebook-bejegyzések tartalmával kapcsolatban, azonban általánosságban szem elött tartandó elv, hogy ne csak egyetlen felhasználói körnek posztoljuk. Ha a követőink között idősebbek is vannak, fontos, hogy számukra is biztosítsunk releváns tartalmakat. A kor mellett érdemes odafigyelni még a nyelvre is. Amennyiben magas az idegen nyelvü követők aránya, bejegyzéseinket célszerü a magyar mellett legalább angolul is közzétenni. Ehhez már remek technikai megoldást kínál a közösségi oldal, egy bejegyzéshez több nyelven tudunk szöveget írni, és minden felhasználó csak a saját beállított nyelvének megfelelő verziót látja.

\section{Instagram $^{6}$}

Az Y generáció szempontjából a második legjelentősebb közösségi felület mára az Instagram lett. Ez egy eredetileg kizárólag mobiltelefonokra szánt képmegosztó szolgáltatás, mára azonban néhány funkciója már számítógépes böngészővel is elérhető. Előszeretettel használják a fiatalok képmegosztásra, hiszen a Facebookkal ellentétben itt kevésbé vannak jelen még szüleik, így olyan képeket is közzétesznek itt, amit Facebookon már nem feltétlenül „mernének”. Az Instagram közösségi elve szerint nem ismerösöket, hanem követőket lehet gyüjteni, illetve követővé válhatunk, ami nem feltételezi a személyes ismeretséget. Ez szintén vonzó szempont a fiatalok számára, akik szívesen kezdeményeznek kommunikációt számukra ismeretlen személyekkel is.

Az Instagram alkalmazását össze lehet kötni Facebook-oldalunkkal is, így azonnal megjelenhet az ott feltöltött bejegyzésünk a Facebookon. (Az Instagram

${ }^{6}$ Elérhető: http://instagram.com. 
a Facebook tulajdona, így az azon keresztül megosztott bejegyzéseket a rendszer előnyben részesíti más hasonló alkalmazásokkal szemben.)

Mivel kifejezetten fényképmegosztó szolgáltatásról van szó, különösen érdemes odafigyelni a fényképek minőségére. Az alkalmazás lehetőséget kínál megosztás előtt a képek szerkesztésére, javítására, különböző effektekkel való „feldobására”. Amennyiben lehetőségünk van rá, négyzet vagy álló képeket posztoljunk, mert a felhasználók többsége álló képernyőn nézi mobiltelefonján keresztül, így egy fekvő kép nagyon apró méretben jelenik meg.

Jellemzően az Y generáció használja ezt a szolgáltatást, az ELTE Egyetemi Könyvtár követőinek háromnegyede ebbe a korosztályba sorolható.

\section{Facebook vs. Instagram}

Felmerülhet a kérdés, melyik szolgáltatással érhetünk el több felhasználót, melyiken válthatunk ki több aktivitást. Az Egyetemi Könyvtár tapasztalatai alapján egyértelmüen kijelenthető, hogy az Instagram vezet e téren. Az ide feltöltött bejegyzések átlagosan a követők kétharmadát érték el, és az elért felhasználók 10-15 százaléka reagált is a bejegyzésekre. Ezzel szemben a Facebookra feltöltött bejegyzéseket mindössze a követők harmada látta, reakciót pedig az elért felhasználók 1-3 százalékából váltottak ki.

\begin{tabular}{|l|c|c|}
\hline & Facebook & Instagram \\
\hline Követök száma & 3271 & 1242 \\
\hline Elért felhasználók száma & 1059 & 867 \\
\hline Elért felhasználók aránya a követőszámhoz képes & $32,4 \%$ & $69,8 \%$ \\
\hline Reakciók/lájkok száma & 42 & 168 \\
\hline Reakciók/lájkok aránya a követőszámhoz képes & $1,3 \%$ & $13,5 \%$ \\
\hline
\end{tabular}

1. táblázat. Egyidőben posztolt, ugyanazon fénykép által kiváltott reakciók a két oldalon

\section{További közösségi oldalak}

Talán többek is egy másik közösségi oldalt, a Twittert ${ }^{7}$ várták második helyre az Instagram helyett. Azonban az Egyetemi Könyvtár tapasztalatai alapján Magyarországon a Twitter kevésbé népszerü, a kitett tweet-ekre elenyésző számban érkezik visszajelzés, s azok is jellemzően felhasználóink helyett más könyvtáraktól.

Bár elsődlegesen nem közösségi oldal, de említést érdemel még a YouTube ${ }^{8}$ is, ahol szintén képviselteti magát néhány könyvtár egy-egy fiókkal. Azonban a tapasztalat az, hogy - elsősorban emberi erőforrás hiánya miatt -, nincs kapacitás

\footnotetext{
${ }^{7}$ Elérhetö: http://twitter.com.

${ }^{8}$ Elérhetö: http://youtube.com.
} 
a könyvtárakban folyamatos videóanyag elöállítására, ezért ritkán frissülnek ezek a YouTube-csatornák.

\section{Könyvtári weboldal}

Ha online jelenlétről beszélünk, nem szabad megfeledkezni a könyvtárak saját weboldaláról sem, hiszen ez is egy olyan felület, ahol sok esetben elsőként tájékozódnak a különböző szolgáltatásokról az egyetemisták. Bizonyos szempontból ez egy nehezebb terep, mert itt sokkal nagyobb kihívás differenciált tartalmat létrehozni, mégis minden számára releváns információt ugyanúgy meg kell találnia rajta egy fiatalnak, mint egy idősebb látogatónak. Ezt elsősorban azzal tudjuk biztosítani, hogy az egyes tartalmakat többféle szempont alapján is elérhetővé tesszük.

Ebben a szellemben készült el az ELTE új könyvtári weboldala, melyet a hallgatók a 2016-2017-es tanév őszi félévének elején kezdhettek el használni. Az Eötvös Loránd Tudományegyetem széttagolt könyvtári hálózattal rendelkezik, csaknem 50 kisebb-nagyobb könyvtár összessége alkotja az Egyetemi Könyvtári Szolgálatot, melynek első honlapja 2011-ben készült el. Az akkori könyvtárközpontú szemlélet kevésbé alkalmazkodott a fiatalok gondolkodásmódjához, hiszen először mindig egy könyvtárat kellett kiválasztaniuk, ha az elérhető szolgáltatásokról akartak tájékozódni. Az Y generáció kevésbé helyhez kötött, őket inkább az érdekli, hogy a számukra éppen szükséges szolgáltatást hol tudják a leggyorsabban, legkönnyebben megközelíthetően igénybe venni. Ezt a gondolkodásmódot követve - de megtartva a korábbi felépítésre jellemzö feltérképezés lehetőségét is - jött létre egy szolgáltatásközpontú weboldal. A kiindulópont a szolgáltatás és az elérhetőség ellenőrzése után ajánlja fel azokat a „szolgáltatási helyeket”, ahol azt igénybe lehet venni. A helymeghatározással való támogatásnak köszönhetően a felhasználó azt az információt is azonnal látja, hogy a szolgáltatás legközelebb hol vehető igénybe, és akár azonnali útvonaltervezésre is van lehetöség.

További, elsősorban fiatalokat célzó szolgáltatás, hogy az ELTE tanulmányi rendszerében használt azonosítóval (Neptun-kód) bejelentkezve már a könyvtári honlapon figyelmeztetéseket jelenítünk meg, ha az olvasónak például lejáró kölcsönzése vagy készpénztartozása van. Ehhez korábban be kellett jelentkezni a teljesen egyedi azonosítást használó online katalógusba. Ha valaki - például saját gépén - bejelentkezve marad, és bármilyen ügyből kifolyólag meglátogatja az Egyetemi Könyvtári Szolgálat weboldalát, akkor automatikusan megjelennek neki ezek a fontos figyelmeztetések.

Fontos egy weboldalnál az is, hogy mobileszközökről is könnyen használható legyen. Ez a témám szempontjából azért is kiemelendő, mert a fiatal generáció előszeretettel használja ezeket az eszközöket internetezésre. A mobilon 
is használható weboldalaknak alapesetben két jól elkülöníthető fajtája van. Az egyik a reszponzív honlapok, melyek képernyőméret függvényében automatikusan átrendeződnek, általában egy hosszú oszlopszerü elrendezésre okostelefonos képernyőn. A második lehetőség egy különálló mobil weboldal létrehozása, melynek a felülete kifejezetten mobileszközre készül, ezért ez kényelmesebb használhatóságot biztosít, mint egy automatikus átrendezés. Ugyanakkor hátránya, hogy külön kell „gondozni”, hiszen különálló oldalról van szó.

Az Egyetemi Könyvtári Szolgálat új honlapjánál ezt a két megközelítést vegyítettük, amely kényelmes használhatóság mellett nem igényel külön adminisztrációt. Ezt úgy értük el, hogy a különálló, kifejezetten mobileszközökre szánt jQuery Mobile felhasználói felülethez a tartalmi elemeket a normál holnapot kezelő Drupal tartalomkezelő rendszer adatbázisából közvetlenül nyerjük ki, így nem szükséges két helyen frissíteni a tartalmakat.

\section{Összegzés}

Bár a könyvtárakat sokan ,múltbeli” intézményeknek tekintik, azonban ezzel a sztereotípiával nem szabad azonosulni. Meg kell keresni azokat a lehetőségeket, ahol meg tudjuk mutatni, hogy a könyvtárak tartják a lépést az idővel a szolgáltatásaik terén. Erre nagyon jó felületet biztosítanak a közösségi oldalak és saját honlapjaik, annál is inkább, mivel az Y és az azt követő generációkkal elsődlegesen ezeken a felületen tudjuk közvetlenül felvenni a kapcsolatot, azzal a céllal, hogy a jövőben szolgáltatásaink felhasználójává váljanak.

\section{Rezümé}

Napjainkban az egyetemisták túlnyomó többségét a Y generáció tagjai, vagyis az 1980 és 1994 között született fiatalok teszik ki. Ök már úgy nőttek fel, hogy életük szerves részévé vált az online kommunikáció, amit a könyvtáraknak is figyelembe kell venni, ha meg akarják szólítani őket. Ez a korosztály mindent „most és azonnal” akar, lehetőleg úgy, hogy ne kelljen elmozdulni a monitor/kijelző elől. Elsődleges információforrásuk az internet, ami alatt nemcsak az online keresőket, hanem az online kapcsolattartás által biztosított lehetőségeket is értem.

Magyarországon a legnépszerúbb közösségi szolgáltatások, ahol könyvtárak is jelen lehetnek, a Facebook és az Instagram. Ha felsőoktatási könyvtárként azt akarjuk, hogy a fiatalok tudomást szerezzenek rólunk, egyre lényegesebb, hogy ezeken a felületeken (is) jelen legyünk. Mindegyiknek megvannak a sajátosságai, amelyekre érdemes odafigyelni, ha könyvtári profilokat üzemeltetünk. Nem szabad szinkronban ugyanazokat a tartalmakat közzétenni minden közösségi oldalon, mivel más felhasználói réteg használja az egyes szolgáltatásokat. Általánosságban elmondható, hogy ha az Y generációt akarjuk elérni, akkor törekedni kell a rövid és tömör tartalmakra, melyeket vizuális elemekkel is kiegészítünk. 


\section{How to Communicate with Generation Y on Online Platforms?}

Today the vast majority of the students are the members of Generation Y, people born between 1980 and 1994. They grew up with online communication in their lives, and a library that would like to address them should take this into consideration. This generation has a "now and immediately" attitude, and they try to avoid to move from the screen. The Internet is their primary source of information, which means not only the online search engines, but also the online social media.

In Hungary the most popular social media websites where libraries can be present are Facebook and Instagram. If we, as a university library want young people to become aware of us, it's very important for us to use these platforms, too. Each platform has its own characteristics, which are worth paying attention to when creating the profile of the library. Different contents should be published on different social sites as different groups of users use them. Generally speaking, if we want to connect to the Y generation, we must focus on the shortness and conciseness of the message, and add some visual content, too.

GARAMVÖLGYI LÁSZLÓ

informatikus könyvtáros

ELTE Eötvös Loránd Tudományegyetem Egyetemi Könyvtár 